\title{
EFEKTIVITAS PERASAN ASAM JAWA (Tamarindus indica L) TERHADAP PERTUMBUHAN BAKTERI Aeromonas hydrophila DENGAN METODE DIFUSI KERTAS CAKRAM
}

\section{EFFECTIVENESS OF ThAMARIN JUICE (Tamarindus indica L) ON GROWTH OF BACTERIA Aeromonas hydrophila WITH PAPER DISC DIFFUSION METHOD}

\author{
Rizky Aprilia Chrisanti, Laksmi Sulmartiwi dan Prayogo \\ Fakultas Perikanan dan Kelautan Universitas Airlangga \\ Kampus C Mulyorejo - Surabaya, 60115 Telp. 031-5911451
}

\begin{abstract}
Fish disease is one of the serious problems that faced by the farmers potentially to make high disadvantages as follows, mortality of fish and fish quality decrease, therefore economically will caused price decrease. Bacterial pathogens were one of the problems that were faced by fish farmers, which cause $90 \%$ of mortality. Diseases control caused by Aeromonas hydrophila in general using by antibiotics. Antibiotics are commonly used were tetracycline, oxolinic acid, erytromicin, streptomycin, and chloramphenicol. Using of antibiotics has shown good results, but on the other hand using of antibiotics or antibacterial cultivation would increased the bacteria number of resistant to antibiotics.

This research was purposed to find the alternative treatment of Motile Aeromonas Septicemia by determination ability of a squeeze of tamarind (Tamarindus indica L) and the minimum concentration of tamarind (Tamarindus indica L) to inhibit the growth of Aeromonas hydrophila. The function of tamarind as an antibacterial because they contain antibacterial substance such as flavonoids and saponins.

The results showed that the antibacterial power of tamarind juice has antibacterial power against Aeromonas hydrophila. Based on a sentsitivity test was performed according to standard of antibiotic concentrations that are common to Aeromonas hydrophila, was Tetracycline inhibition zone with $<15 \mathrm{~mm}$ diameter (not sensitive), $15-18 \mathrm{~mm}$ (moderately susceptible), $>18 \mathrm{~mm}$ (very sensitive) is A (10\%), and B (12.5\%), treatment inhibition zone subsequently $13 \mathrm{~mm}$ and $14.3 \mathrm{~mm}$ (insensitive), C (15\%), D (17.5\%), with inhibition zone $15.5 \mathrm{~mm}$ and $16.6 \mathrm{~mm}$ (self-sensitive) and 20\% with inhibition zone diameter of 19 $\mathrm{mm}$ (highly sensitive). Therefore, it was concluded that A treatment (15\%) with inhibition zone $15.5 \mathrm{~mm}$ showed the inhibition ability of Aeromonas hydrophila growth.
\end{abstract}

Keywords : Tamarindus indica L, Aeromonas hydrophil, Paper disc diffusion method

\section{Pendahuluan}

Bakteri patogen merupakan salah satu masalah yang dihadapi oleh pembudidaya ikan, yang dapat menyebabkan kematian hingga $90 \%$ (Marlina, 2008). Aeromonas hydrophila merupakan jenis bakteri yang banyak ditemukan di perairan tawar, bakteri ini juga dapat menginfeksi hewan air bahkan manusia. Aeromonas hydrophila menyebabkan penyakit Motile Aeromonas Septichemia (MAS) atau penyakit bercak merah. Bakteri ini menyerang berbagai jenis ikan air tawar.

Penanggulangan penyakit yang diakibatkan oleh bakteri Aeromonas hydrophila pada umumnya menggunakan antibiotika. Penggunaan antibiotika tersebut menunjukkan hasil yang baik, namun dipihak lain pemakaian antibiotika atau antibakteri pada budidaya akan meningkatkan jumlah bakteri yang resisten terhadap antibiotika tersebut (Alderman dan Michel, 1992 dalam Inglis et al., 1997)
Salah satu alternatif yang dapat digunakan untuk pengganti antibiotika adalah bahan alami. Bahan alami yang berpotensi sebagai antibakteri adalah sari buah asam jawa (Tamarindus indica L) Zat kimia dalam asam jawa adalah senyawa tannin, saponin, dan flavonoida (0.35-1.27\%) yang memiliki khasiat sebagai antibakteri. Selain itu, bahan alami tersebut tersedia di alam dalam jumlah berlimpah dan mudah didapat (Amando, 2011)

\section{Metodologi \\ Sterilisasi}

Sterilisasi ditujukan untuk membunuh semua mikroba pencemar, baik mikroba menguntungkan maupun merugikan. Semua peralatan baik alat pembuatan disterilisasi dengan autoklaf dengan suhu $121^{\circ} \mathrm{C}$ tekanan 1,5 atm selama 15 menit (Nugroho, 2004), kemudian dimasukkan pada oven pada suhu $180^{\circ} \mathrm{C}$ selama 1 jam, untuk peralatan yang tidak tahan panas hanya dicuci menggunakan alkohol 
$70 \%$, untuk bahan cairan yang tidak tahan terhadap panas langsung maupun tidak langsung seperti larutan gula - gula dan perasan buah asam jawa proses sterilisasi dapat dilakukan menggunakan metode penyaringan menggunakan filter membran.

Pembuatan Perasan Buah Asam Jawa

Buah asam jawa (Tamarindus indica

L) diperoleh dari koleksi Taman Flora Surabaya. Pembuatan sari buah asam jawa menggunakan buah segar sebanyak $300 \mathrm{~g}$ yang diambil pada bagian buah yang masih muda dengan ciri-ciri kulit buah berwarna coklat kehijauan, kemudian buah dicuci bersih, dikupas, dipisahkan dari kulit dan bijinya dan diambil sarinya dengan menggunakan mortir tanpa ditambahkan Aquadest kemudian disaring dengan saringan, cairan yang tersaring kemudian disentrifuge untuk mendapatkan supernatant.

\section{Identifikasi Bakteri Aeromonas hydrophila} Isolat bakteri Aeromonas Hydrophilla diperoleh dari Balai Karantina Ikan Juanda. Sebagai langkah awal, dilakukan peremajaan terhadap koloni bakteri Aeromonas Hydrophilla. Sebelum digunakan, bakteri dibiakkan terlebih dahulu pada media NA pada cawan petri, media NA yang telah diinokulasi dengan bakteri diinkubasi pada suhu $27-28^{\circ} \mathrm{C}$ selama 24 jam, kemudian dilanjutkan pewarnaan Gram dan uji biokimia untuk memastikan bahwa isolat yang digunakan benar-benar murni Aeromonas hydrophila.

\section{Persiapan Suspensi Bakteri Aeromona hydrophila}

Bakteri Aeromonas hydrophila yang akan digunakan terlebih dahulu disetarakan kekeruhannya dengan standar Mc Farland 1 cara penyetaraan adalah sebagai berikut : mengambil 4-10 koloni bakteri kemudian diencerkan dengan menggunakan larutan $\mathrm{NaCl}$ Fisiologis kemudian disetarakan kekeruhannya dengan Mc Farland 1, sehingga jumlah bakteri yang terdapat didalamnya setara dengan $300 \times 10^{6}$ $\mathrm{sel} / \mathrm{mL}$, kemudian diambil sebanyak $0,2 \mathrm{ml}$ setara dengan 200 mikroliter dengan menggunakan mikropipet terkalibrasi ukuran 100-1000 mikroliter, kemudian diteteskan pada media agar dan diratakan dengan spatula, begitu seterusnya.

Persiapan Perasan Buah Asam Jawa dengan Berbagai Konsentrasi
Metode yang digunakan pada penelitian ini metode difusi dengan berbagai kosentrasi perasan buah asam jawa. menyiapkan 6 tabung reaksi dari konsentrasi $10 \%, 12,5 \%$, $15 \%, 17,5 \%$ dan $20 \%$. Pada tabung konsentrasi $10 \%$ diisi $0,1 \mathrm{ml}$ sari buah asam jawa dan ditambahkan $0,9 \mathrm{ml}$ akuades steril, pada konsentrasi $12,5 \%$ diisi $0,125 \mathrm{ml}$ perasan buah asam dan ditambahkan $0,875 \mathrm{ml}$ akuades, pada konsentrasi $15 \%$ tabung reaksi diisi $0,15 \mathrm{ml}$ perasan buah asam dan ditambahkan $0,85 \mathrm{ml}$ akuades, pada konsentrasi $17,5 \%$ tabung reaksi diisi dengan $0,175 \mathrm{ml}$ perasan buah asam dan ditambahkan $0,825 \mathrm{ml}$ akuades, dan terakhir pada konsentrasi 20\% tabung reaksi diisi dengan $0,2 \mathrm{ml}$ perasan buah asam dan ditambahkan 0,8 $\mathrm{ml}$ akuades. Kemudian dilakukan perendaman kertas cakram sampai jenuh (antara 15-20 menit), setelah itu ditiriskan dan dikering anginkan sampai tidak menetes kemudian kertas cakram yang berisi bahan antibakteri ditanam pada media TSA yang sudah diberi suspensi bakteri yang telah diratakan dengan spatel bengkok.

\section{Penentuan Zona Hambat}

Cara pembacaan hasil sari buah asam jawa terhadap pertumbuhan mikroba Aeromonas hydrophila dengan melihat zona hambat, menggunakan luas zona bening yang dihasilkan di sekitar kertas cakram yang terbentuk kemudian mengukur diameter zona hambat dengan jangka sorong. Diambil satu titik pada tepi zona hambat kemudian ditarik garis tengah, diukur dengan menggunakan jangka sorong dilakukan sebanyak tiga kali pada tepi zona hambat tiap konsentrasi kemudian diambil rata-rata dari ketiga pengukuran. Hasil rata-rata merupakan diameter zona hambat pada konsentrasi tersebut (Caroline, 2010). Hasil pengukuran zona hambat semua perlakuan kemudian dibandingkan dengan zona hambat standar.

\section{Hasil dan Pembahasan}

Berdasarkan hasil uji efektivitas perasan asam jawa dengan pengamatan yang secara visual menunjukkan bahwa konsentrasi perasan asam jawa $10 \%$ sampai $20 \%$ zona hambat yang dihasilkan semakin lebar. Hasil pengamatan secara visual tersebut menunjukkan bahwa semakin besar konsentrasi yang diberikan maka semakin besar zona hambat yang dihasilkan semakin lebar. Dapat dilihat pada Tabel 1. 
Tabel 1. Hasil Pengukuran Rata-Rata Diameter Zona Hambat yang Terbentuk dari Uji Efektivitas Perasan Asam Jawa

\begin{tabular}{|c|c|c|c|c|}
\hline Konsentrasi & Diameter Zona & \multicolumn{3}{|c|}{ Kriteria Diameter Zona Hambat Antibiotika Tertracyclin } \\
\cline { 3 - 5 } Jerasan Asam & Hambat $(\mathrm{mm})$ & $\begin{array}{c}\text { Tidak peka } \\
(15<\mathrm{mm})\end{array}$ & $\begin{array}{c}\text { Cukup peka } \\
(15-18 \mathrm{~mm})\end{array}$ & $\begin{array}{c}\text { Sangat peka }(>18 \\
\mathrm{mm})\end{array}$ \\
\hline A $(10 \%)$ & 13 & $\mathrm{~V}$ & & \\
$\mathrm{~B}(12,5 \%)$ & 14,3 & $\mathrm{~V}$ & $\mathrm{~V}$ & \\
$\mathrm{C}(15 \%)$ & 15,5 & & $\mathrm{~V}$ & $\mathrm{~V}$ \\
$\mathrm{D}(17,5 \%)$ & 16,6 & & & \\
E $(20 \%)$ & 19 & $\mathrm{~V}$ & $\mathrm{~V}$ & \\
F $(0 \%)$ & 0 & & & \\
Tetracicline & 15 & &
\end{tabular}

Hal ini dapat dilihat pada konsentrasi tertinggi yaitu pada perlakuan E $(20 \%)$ zona hambat yang terbentuk sebesar $19 \mathrm{~mm}$, pada konsentrasi terkecil yaitu pada perlakuan A $(10 \%)$ zona hambat yang terbentuk adalah sebesar $13 \mathrm{~mm}$. Hal ini sesuai dengan Jawetz et al (2001) yang mengatakan bahwa daerah hambatan yang terbentuk setelah inkubasi 1824 jam dianggap sebagai ukuran kekuatan suatu antibiotika terhadap kuman yang diperiksa. Namun demikian penggunaan bahan antibakteri di lapangan hendaknya digunakan seminimal mungkin untuk menghambat pertumbuhan bakteri Aeromonas hydrophila.

Menurut Bauer dkk (1966) dalam Volk (1992), Standar umum diameter daerah hambatan pertumbuhan bakteri yang digunakan dalam penelitian ini adalah menggunakan standar antibiotika yang biasa digunakan untuk mengatasi penyakit yang disebabkan oleh Aeromonas hydrophila yaitu antibiotika Tetracycline sebagai pembanding. Tetracycline dikatakan peka apabila zona hambat yang terbentuk sebesar 15-18 mm maka untuk meminimalkan penggunaan bahan dipilih perlakuan $\mathrm{C}(15 \%)$ perasan asam jawa, karena pada perlakuan $\mathrm{C}(15 \%)$ perasan asam jawa sudah mampu menghambat Aeromonas hydrophila sesuai dengan antibiotika pembanding yang biasa digunakan yaitu Tetracycline.

\section{Kesimpulan}

Jenis bahan antibakteri yang terdapat dalam suatu tanaman juga menentukan kemampuan bahan tersebut dalam menghambat pertumbuhan bakteri Aeromonas hydrophila disamping faktor besarnya konsentrasi. Dalam penelitian ini penggunaan buah asam jawa karena didalam buah asam jawa terdapat beberapa senyawa aktif yang bersifat anti bakteri. Kandungan kimia yang terkandung dalam daging buah, daun dan batang tanaman buah asam jawa adalah tannin, saponin, dan flavonoida.

\section{Daftar Pustaka}

Alderman, D. J., and C. Michel. 1992. Chemoteraphy in Aquaculture Today. In: edited by $\mathrm{C}$. Michel and D. J Alderman, 3-24. Paris; Office International des Epizooties.

Amando, Rodriguez, J. 2011. Standardization of The Quality Control Parameters of The Tamarindus indica $L$ Soft extract. Uviversity of Oriente. Santiago de Cuba. Cuba.

Caroline, L. 2010. Daya Hambat Ekstrak Tamarindus Indica Terhadap Pertumbuhan Bakteri pada Recurrent Aphthous Stomatitis (RAS). Skripsi. Fakultas Kedokteran Gigi. Universitas Airlangga. Surabaya.

Volk, W.A. 1992. Basic Microbiology, seventh edition. Harper Collins Publisher Inc. School of Medicine. University of Virginia. New York.

Jawetz E, Melnick GE, and Adelberg E. A. 2001. Mikrobiologi kedokteran. Edisi I. Diterjemahkan oleh Penerjemah Bagian Mikrobiologi Fakultas Kedokteran Universitas Airlangga. Salemba Medika, Surabaya. 224-228

Marlina, L. 2008. Pengaruh Crude Serbuk Sirih (Piper batle) Terfermentasi Terhadap Penghambatan Bakteri Patogen Aeromonas hydrophila Pada ikan Gurame (O. gouramy), Skripsi. Program Studi Sarjana Mikrobiologi SITH. Institut Teknologi Bandung.

Nugroho, A. 2004. Pedoman Pelaksanaan Teknik Kultur Jaringan. Penebar Swadaya. Jakarta. 